\title{
A novel passerivirus(family Picornaviridae) in an outbreak of enteritis with high mortality in estrildid finches (Uraeginthus sp.)
}

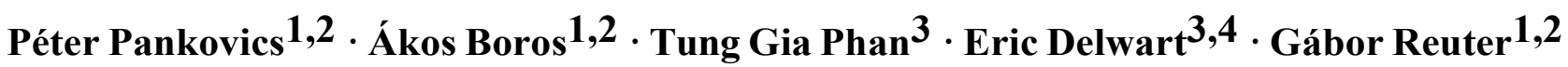

Gábor Reuter reuter.gabor@gmail.com

1 Regional Laboratory of Virology, National Reference Laboratory of Gastroenteric Viruses, ÁNTSZ Regional Institute of State Public Health Service, Pécs, Hungary

2 Department of Medical Microbiology and Immunology, Medical School, University of Pécs, Szigeti út 12, Pécs 7624, Hungary

3 Blood Systems Research Institute, San Francisco, CA, USA

4 University of California, San Francisco, CA, USA 


\begin{abstract}
An enteric outbreak with high mortality $(34 / 52,65.4 \%)$ was recorded in 2014 in home-reared estrildid finches (Estrildidae) in Hungary. A novel passerivirus was identified in a diseased violeteared waxbill using viral metagenomics and confirmed by RT-(q)PCR. The complete genome of finch picornavirus strain waxbill/DB01/HUN/2014 (MF977321) showed the high- est amino acid sequence identity of $38.9 \%, 61.6 \%, 69.6 \%$ in $\mathrm{P} 1{ }^{\mathrm{cap}}, 2 \mathrm{C}^{\text {hel }}$ and $3 \mathrm{C}^{\mathrm{pro}} \mathrm{D}^{\mathrm{pol}}$, respectively, to passerivirus $\mathrm{A} 1$ (GU182406). A high viral load $\left(6.58 \times 10^{10}\right.$ genomic copies $\left./ \mathrm{ml}\right)$ was measured in a cloacal specimen and in the tissues (spinal cord, lung, and the intestines) of two additional affected finches. In addition to intestinal symptoms (diarrhoea), the presence of extra-intestinal virus suggests a generalized infection in this fatal disease, for which the passerivirus might be a causative agent.
\end{abstract}

Keywords Passerivirus, Dead bird, Estrildid finch, Picornavirus, Gastroenteritis

The GenBank[/EMBL/DDBJ] accession number for the study sequence: MF977321-MF977323. 
Picornaviruses are small, non-enveloped viruses of the family Picornaviridae that have a positivesense, single- stranded RNA genome [1]. The RNA genome starts with 5'untranslated region (UTR) containing either an SL-A/B/C cloverleaf fold or the origin of replication (ORI) region, fol- lowed by an internal ribosomal entry site (IRES) [2-7]. Generally, with the exception of the dicipiviruses [8, 9], a single polyprotein is translated from the viral RNA genome and is cleaved into smaller viral capsid (structural) proteins and non-structural proteins [1, 10]. In addition, many picornaviruses encode a leader (L) protein before the P1 region, which has diverse functions [11, 12]. Located in different genomic positions, a cis-acting replication element (CRE) is also present in picornavirus genomes [6, 7 , 12-15]. The viral RNA genome ends with a 3'UTR, which contains structur-poly(A) tail [16]. The host range of picornaviruses is wide, including both lower and higher vertebrates [http://www. picornaviridae.com].

The estrildid finches are very popular hobby birds in Hungary. These birds are members of the family Estrildidae, class Aves order Passeriformes [17; https://www.itis.gov; http://www.hbw.com/order/passeriformes], which currently includes 30 genera with 158 species [18; http://www.hbw.com/ibc/family/waxbills-estrildidae]. The estrildid finches naturally originated in India, Australia, and the Indian and South Pacific islands, but the most ancient groups are from Africa [18]. Generally, estrildid finches are small birds that are approximately 8 to 17 centimetres long with an average weight of 7.5 grams. The plumage colour and pattern are varied, but their habitat and eating habits are similar [18, 19]. Their diet consists mostly of seeds (Panicum miliaceum, Setaria italica, Phalaris canariensis) and greens (Stellaria media, Lactuca sativa, Plantago major) or wild furrow-weeds (Poa annua, Poa pratensis, Setaria viridis) [18, 19], but during their reproduction period, high-protein-content foods (Formica rufa, Tenebrio molitor, Daphnia magna) are needed (T. Jantyik personal communication). Frequently, birds for home-rearing are collected from the wild by a stock farmer, often shortening or neglecting the quarantine time and exposing the isolated bird population to external infections.

In this study, using viral metagenomics and molecular methods, a novel passerivirus was identified in cloacal and tissue samples of dead estrildid finches (Estrildidae) in Hungary and characterized.

A gastroenteric outbreak with high mortality (34/52, 65.4\%) occurred in 2014 in the town of Békés, Hungary, in the finch population, including six violet-eared waxbills (Uraeginthus granatinus), six purple grenadiers (Uraeginthus ianthinogaster) and 22 red-cheeked cordon-bleus (Uraeginthus bengalus) in the genus Uraeginthus. Additionally, four red avadavats (Amandava amandava) and four orange-breasted waxbills (Amandava subflava) in the genus Amandava, four Gouldian finches (Erythrura gouldiae) in the genus Erytrura, four red-billed firefinches (Lagonosticta 
senegala) in the genus Lagonostica and two crimson finches (Neochmia phaeton) in the genus Neochmia were kept in the aviary. All birds were kept together in a $2.5 \times 2.5$-metre aviary in a closed building (with walls and a roof) and allowed access to the same water and feed. According to information from the stock farmer, six breeding pairs of violet-eared waxbills were bought from Holland, and six breeding pairs of wild purple grenadiers were bought from Africa. The red-cheeked cordon-bleus were reared locally. All birds of the family Estrildidae were breeding pairs of reproductive age except the violet-eared waxbills, purple grenadiers and red-cheeked cordon-bleus, which were younger than 2 years old. An enteric outbreak occurred seven to ten days after the violeteared waxbills and purple grenadiers were introduced into the farm. The recommended 30-day quarantine was not complied with. At first, all violet-eared waxbills, purple grenadiers and redcheeked cordon-bleus (members of the same genus) sat languidly with plumped feathers and with their heads bent (nonspecific signs). From this point in time, the appetites of these birds increased, and they mostly showed a preference for mealworms, the larval form of the meal- worm beetle Tenebrio molitor, but these birds nonetheless lost weight during several episodes of watery diarrhoea. After the first death, a faecal sample and two dead birds were taken to the local animal hospital for routine bacterial and parasitic examination on November 14, 2014. Hepatosplenomegaly and enteritis were observed during the necropsy of both birds. Bacterial cultivation of liver suspensions in agar slants and modified Drigalszki agar, and STAM staining of liver samples yielded negative results. A flotation assay for parasites in faecal samples from both dead birds gave a negative result for coccidian-like oocyst bodies and cestodes, nematode eggs and adult worms. A total of 34 finches of the genus Uraeginthus died during the observation period, but other birds kept in the same aviary remained asymptomatic.

The carcases of three violet-eared waxbills (DB01, DB02 and DB03) were also collected by the stock farmer. A cloacal sample from a single bird (DB01) was chosen for viral metagenomics analysis, and corpses were stored at $-80^{\circ} \mathrm{C}$. The cloacal sample was diluted in $500 \mu$ of phosphatebuffered saline (PBS) for extraction of total nucleic acid. The suspension was passed through a $0.45-$ $\mu \mathrm{m}$ sterile filter (Millipore) and centrifuged at $6,000 \times g$ for $5 \mathrm{~min}$. The filtrate was then treated with DNase and RNase [20]. Viral particle- protected nucleic acids were extracted using a QIAamp spincolumn kit (QIAGEN), amplified by sequence-independent random RT-PCR, and subjected to viral metagenomics analysis [21]. A viral cDNA library was constructed using a ScriptSeqTM v2 RNASeq Library Preparation Kit (Epicentre), and it was sequenced on a MiSeq Illumina platform as described previously [20]. Reads and assembled contigs longer than $100 \mathrm{bp}$ were compared to sequences in the GenBank protein database (BLASTx), using a cutoff value (E-value) of $10^{-10}$. 
RNA was extracted from a 300- $\mu$ l cloacal suspension using TRI Reagent (Molecular Research Centre, Cincinnati, OH, USA) [22]. Sequence-specific primers were designed for the verification of viral metagenomics reads/contigs and to obtain the complete viral RNA genome sequence using various PCR methods [23, 24]. PCR products were sequenced directly and run on an automated sequencer (ABI Prism 310, Applied Biosystems, Stafford, USA). In addition, the organs (midbrain, spinal cord, heart, lung, liver, kidney, pancreas, proventriculus, gizzard, small- and large-intestinal tracts) of two dead violet-eared waxbills - DB02 and DB03 - were also tested by RT-PCR.

The primer pairs used for screening, S13-Passeri-3D-R (5'-CCTCCCAGATCATGTAGT-3', corresponding to nt position 8699-8716 of waxbill/DB01/HUN/2014) and S13-Passeri-3D-F (5'CCTTATGGTTGGAGGCAA-3', corresponding to nt position 8256-8273 of waxbill/DB01/HUN/2014), were designed based on the 3Dpol contig sequence of the isolate from this study. For quantitative RT-PCR, cDNA was synthesized using reverse primer S13-Passeri-3D-R and then amplified using primers (DB01-qPCR-standR (5'-GCATACAGCACATCATCTCCA-3', corresponding to nt position 8391-8411) and DB01-qPCR-standF (5'AGGCAACCCCTCTGGCTGTGT-3', corresponding to nt position 8268-8288) using a real-time PCR system (LightCycler FastStart DNA Master SYBR Green I, Roche, Mannheim, Germany). For absolute quantification and the generation of a standard curve, a 100-fold dilution series of a single PCR amplicon of the isolate was purified on a silica column (QIAGEN, Hilden, Germany), quantified spectrophotometrically, and used for qPCR analysis. Three technical repeats were performed.

The probable initiation start codon (AUG) was identified using the $\mathrm{ATG}^{\mathrm{Pr}}$ prediction program (http://atgpr.dbcls.jp/), and a probable N-terminal myristoylation signal identified using NMT - The MYR Predictor (http://mendel.imp.ac.at/ myristate/SUPLpredictor.htm).

Multiple nucleotide (nt) sequences of representative picornaviruses and the isolate from this study were aligned based on codons, using MEGA 6.06 [25], and their predicted amino acid (aa) sequences were compared using BioEdit ver. 7.2.5 [26]. A hypothetical cleavage map of the picornavirus polyprotein was derived from alignments with the closest relative, the picornavirus passerivirus A1 (genus Passerivirus) strain thrush/Hong Kong/00356/2007 (GU182406).

All evolutionary analyses were conducted in MEGA 6.06. The nucleotide sequences of representative picornaviruses and the isolate from this study were aligned by the ClustalW codonbased method and pre-tested in a best-nt/ aa-model (maximum likelihood, ML) search. Dendrograms were constructed by the ML method based on the general time-reversible model with gamma distribution $(+\mathrm{G})$ and invariable sites $(+\mathrm{I})$.

The secondary RNA structures of the 5' and 3'UTRs, including the IRES, were predicted using 
RNAstructure [27] and ViennaRNA Web Service [28] with manual correction as described previously $[4,29]$.

The complete sequence of waxbill/DB01/HUN/2014 and the partial 3Dpol sequences of waxbill/DB02-DB03/HUN/2014 were submitted to GenBank under accession numbers MF977321MF977323.

In 2014, a cloacal sample was collected from a dead DB01 violet-eared waxbill (Uraeginthus granatinus) and subjected to viral metagenomics analysis. After in silico analysis and de novo assembly, 10,393 sequence reads were obtained that showed similarity to viruses (BLASTx cutoff E score $\leq 10^{-10}$ ). The detected sequences for which more than 15 reads were obtained were from the virus families Picornaviridae $(\mathrm{N}=9363)$, Microviridae $(\mathrm{N}=212)$, Circoviridae $(\mathrm{N}=62)$, Caliciviridae $(\mathrm{N}=39)$, Tombusviridae $(\mathrm{N}=17)$, "other" $(\mathrm{N}=116)$ and "unclassified" $(\mathrm{N}=584)$. The reads corresponding to the virus family Picornaviridae were selected, and approximately $75 \%$ of the viral genome was assembled (data not shown). S13-Passeri-3D-R/F primer pairs were used to verify the presence of the viral RNA in the cloacal sample.

The complete RNA genome of strain waxbill/DB01/ HUN/2014 (MF977321) is $9130 \mathrm{nt}$ long, excluding the poly(A) tail. The genome organization is as follows: $5 \mathrm{UTR}^{\mathrm{IRES}-\mathrm{V} / \mathrm{L} / \mathrm{P} 1(\mathrm{VP} 0-\mathrm{VP} 3-}$

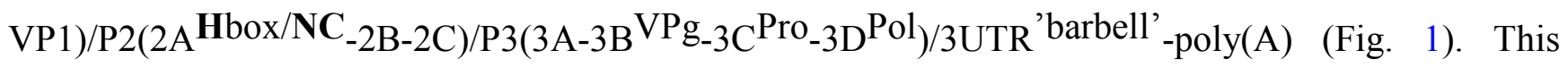
iso- late has a $\mathrm{G}+\mathrm{C}$ content of $48.28 \%$ and a nucleotide distribution of $26.4 \% \mathrm{~A}, 25.3 \% \mathrm{U}, 21.95 \% \mathrm{G}$ and $26.3 \% \mathrm{C}$. 


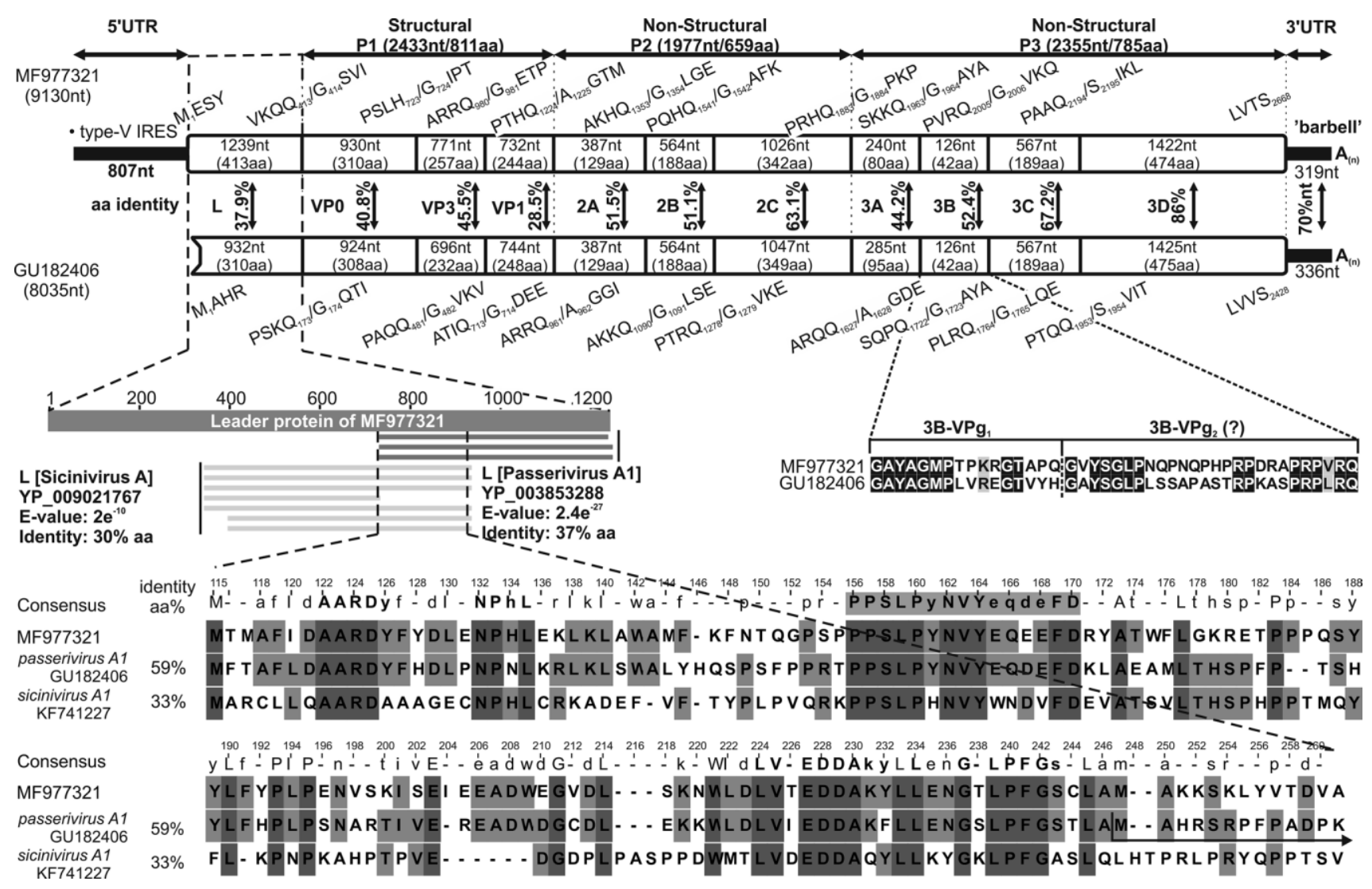

Fig. 1 Comparison of the genome organization of finch picornavirus strain waxbill/DB01/HUN/2014 (MF977321) with that of its closest relative, passerivirus A1 strain thrush/Hong Kong/00356/2007 (GU182406, NC_014411), a member of the genus Passerivirus. Genome lengths - excluding the poly(A)-tail - are indicated below the strain name; the nucleotide (nt) and amino acid (aa) lengths of the hypothetical genes are indicated in the gene boxes. The predicted aa cleavage sites are shown at the borders of the regions. Pairwise aa sequence identity scores are shown between the related protein products. The comparative alignment of the leader (L) protein of the study strain and the closest match in based on a GenBank BLASTp search. The L protein of the study strain has 37\% (E-value: $2.4 \mathrm{e}-27$, query cover: $40 \%$ ) and $30 \%$ (E-value: $2.4 \mathrm{e}-$ 10, query cover: 40\%) aminoacid sequence identity to the leader proteins of passerivirus A1 strain thrush/Hong Kong/00356/2007 (GU182406) and sicinivirus A1 strain ch/UCC001/Eire (KF741227, NC_023861), respectively. The presumed 5'UTR nt sequence of strain thrush/Hong Kong/00356/2007 (GU182406) [34] encodes a potential L protein product that partially overlaps part with that of sicinivirus A1 strain ch/UCC001/Eire (KF741227). The hypothetical initiation site of the prototype passerivirus A1 [34] is indicated by a black arrow. The conserved aa motifs are bolded in the consensus sequence, and the PPSLP amino acids are indicated in grey. The aa sequence alignment of the 3B-VPg region of the isolate from this study and the prototype passerivirus A1 strain indicates the two hypothetical copies of 3B-VPgs

The 5'UTR of the studied strain is $807 \mathrm{nt}$ long (Fig. 1, 2A/B). The first in-frame AUG initiation codon is at nt position 808-810 (AAAAso8UGG) with an optimal Kozak context (GxxAUGG) [30] (Fig. 2A/B). In the GenBank database, 68\% nucleotide sequence identity was found from nt 405 to nt 635 between this strain and the type-V IRES of the oscivirus thrush/Hong Kong/10878/2006 (GU182410) (from nt 253 to nt 476) as the closest match (Fig. 2B). Based upon this nt sequence 
identity and the results of secondary RNA structure predictions, this isolate was found to have a potential aichivirus-A-like type-V IRES (Fig. 2A/B). Domains H, I, J, K, L and the $\mathrm{Y}_{(\mathrm{n})}-\mathrm{X}_{(\mathrm{m})}-\mathrm{AUG}$ motif are characteristics of type-V IRES elements and were found in the studied sequence $[4,31,32]$. 'Loop B', the conserved GNRA tetraloop nucleotide motif in domains $\mathrm{Ja}$ and $\mathrm{Jb}$, and the modified eIF4G-binding motifs AGGTACCCG (nt 591 to 599) and CGGATGTGGA (nt 610 to 618) in domain $\mathrm{K}$ were also found in the IRES of our isolate [4]. The shape and structural elements of domains $\mathrm{D} /\left(\mathrm{D}^{\prime}\right), \mathrm{E} /\left(\mathrm{E}^{\prime}\right), \mathrm{G} /\left(\mathrm{G}^{\prime}\right)$ were not identifiable [4]. Interestingly, we were unable to identify the origin of replication (ORI), which is usually present at the 5' terminal end of the 5'UTR in type-V IRES elements [4], but three potential hairpin structures were found. The pyrimidine-rich region (Y: nt 653 to nt 673 ) and a spacer (X: nt 674 to nt 807 ) were identified and has $51 \%$ nt sequence identity to those of oscivirus A1 (GU182410).

The 3'UTR is $319 \mathrm{nt}$ long and has $70 \%$ nucleotide sequence identity to the corresponding region of passerivirus A1 strain thrush/Hong Kong/00356/2007 (GU182406) (Fig. 1). It is also predicted to contain a 'barbell-like' secondary RNA structure (Fig. 2C) [16, 29].

The nucleotide sequence motif AAAC/G forms the cis-acting replication element (CRE) [7, 15] and is presumed to be active when present in the apical loop of the secondary structure $[4,6,7,15]$. Based on RNA secondary structure prediction, the thermodynamically most favoured site ( $\mathrm{A}_{1338} \mathrm{AACG}$ or $\mathrm{A}_{1346} \mathrm{AACA}$ in the loop of the structure with $\Delta \mathrm{G}=-21.1 \mathrm{kcal} / \mathrm{mol}$ ) of CRE motifs is located between $\mathrm{nt}$ 1338 and 1342 or nt 1346 and 1350 in the L protein coding region (Fig. 2D). The genome of the isolate from this study encodes a 2255 -aa-long polyprotein that is cleaved into proteins through a posttranslational cleavage cascade (Fig. 1). 


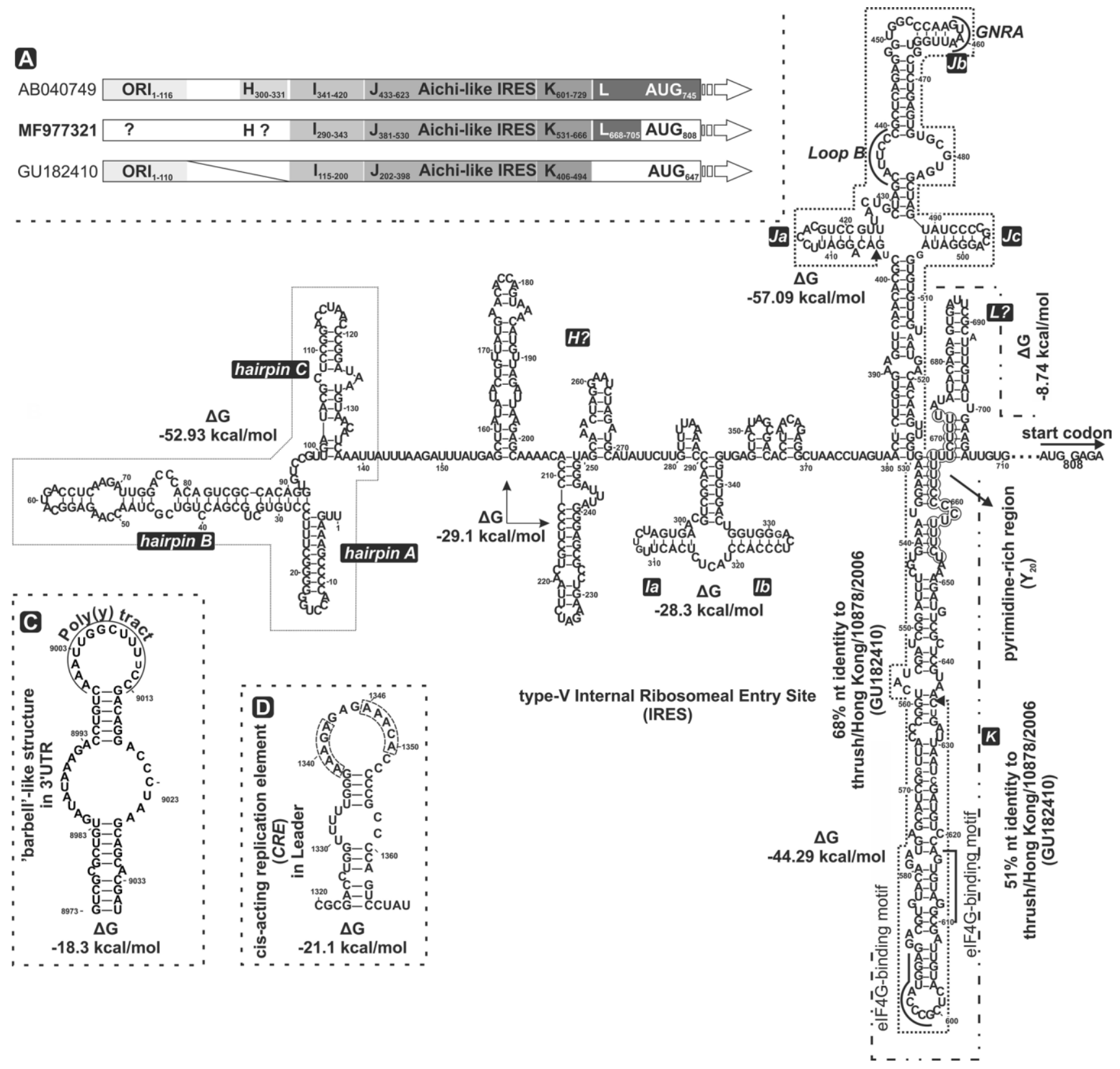

Fig. 2 Predicted RNA secondary structures of finch picornavirus strain waxbill/DB01/HUN/2014 (MF977321). A) Schematic representation of the 5'UTR of the study strain based on similarities to the corresponding parts of the closest relative oscivirus A2 (genus Oscivirus) strain thrush/Hong Kong/10878/2006 (GU182410) and aichivirus A (genus Kobuvirus) strain A846/88 (AB040749). Domains H, I, J, K and L are labelled, indicating the starting and ending nucleotide positions, and the initiation codon of each polyprotein is shaded. B) Secondary structure model of the finch picornavirus 5'UTR, including a type-V internal ribosomal entry site (IRES) [4, 29]. The shape and structural elements of domains I, J and $\mathrm{K}$ were identified, and domains $\mathrm{H}$ and $\mathrm{L}$ were hypothesized. The structural elements D, E, F and $\mathrm{G}$ were not identified in the studied strain. The conserved 'loop B' and nucleotides GNRA (GUAA) were identified in domain Ja and $\mathrm{Jb}$, respectively. Nucleotides indicated by dotted lines showed $68 \%$ and $51 \%$ nt sequence identity to oscivirus A2 (genus Oscivirus) strain thrush/Hong Kong/10878/2006 (GU182410). The essential pyrimidine-rich $\mathrm{Y}_{(\mathrm{n})}$ motif between domains K and L and the putative in-frame AUG start codon (start from nt 808) are indicated. The predicted 'barbell-like' RNA secondary structure in the 3'UTR (C) and the cis-acting replication element (CRE) in the leader (L) protein (D) were 
modelled in silico. The position of the poly $(\mathrm{Y})$ tract in the 'barbell-like' structure and the two alternate CREs are indicated by dotted lines in the apical loops of the structures

Potential polyprotein cleavage sites were predicted based on a comparison with the prototype passerivirus A1 strain thrush/Hong Kong/00356/2007 (GU182406) as the closest relative (Fig. 1). The putative L protein is $1239 \mathrm{nt}$ (413 aa) long, and a BLASTx search showed 37\% aa sequence identity to the closest match, passerivirus A1 strain thrush/Hong Kong/00356/2007 (GU182406) and 30\% aa sequence identity to sicinivirus A1 strain ch/UCC001/Eire (KF741227) in the corresponding region (Fig. 1). The putative 5'UTR of strain thrush/Hong Kong/00356/2007 [8] is in fact a proteinencoding nucleotide sequence based on our analysis, and the predicted protein has $59 \%$ aa sequence identity to the $\mathrm{L}$ protein of the isolate from this study. Several conserved amino acid motifs, including $\mathrm{A}_{122} \mathrm{ARD}, \mathrm{P}_{1569} \mathrm{PSLP}$ (PxLPxNxxxxxxFD), $\mathrm{E}_{22} \mathrm{DDA}$ and $\mathrm{L}_{239} \mathrm{PFG}$, were detected in both picornaviruses, which could indicate a homologous function of this protein and suggest that the published genome sequence of the prototype passerivirus A1 strain is not complete (Fig. 1) [33]. The P1 structural and P2 and P3 non-structural regions are 2433 nt (811 aa), $1977 \mathrm{nt}(659 \mathrm{aa})$ and $2355 \mathrm{nt}$ (785 aa) long, respectively. A potential N-terminal myristoylation motif (GxxxT/S, $\mathbf{G}_{414} \mathrm{SVIYN}$ ) was present at the N-terminal end of the hypothetical VP0 protein. The conserved $\mathbf{H}$-box/NC amino acid motifs $\left(\mathbf{H}_{1249} \mathrm{WAI}\right.$ and $\left.\mathbf{N}_{1308} \mathbf{C T N W}\right)$ in $2 \mathrm{~A}$; the conserved Walker A (GxxGxGKS, G1673KPGSGKS), Walker B (DDLxQ, D ${ }_{1724}$ DIGQ) and Walker C (KGxxxxSxxxxx(S/T)(S/T) N, K1757GMTYTSKVIIMTSN) motifs in 2C were also identified. Interestingly, the $3 \mathrm{~B}$ protein is 42 amino acids long, suggesting that there are potentially two copies of unequally long VPgs encoded likewise in the genome of the prototype passerivirus A1 strain (Fig. 1). The RNA-binding domain (KFRDI, Q2086CRDI), the modified picornavirus $\mathrm{H}-\mathrm{D}-\mathrm{C}$ catalytic triad $\left(\mathrm{TDV}_{2135} \mathrm{Y}\right.$ and $\left.\mathrm{GLC}_{2147} \mathrm{G}\right)$, the histidine $\left(\mathbf{H}_{2167} \mathrm{VAG}\right)$ residue in the trypsin-like protease domain in $3 \mathrm{C}$, and well-conserved aa motifs ( $\mathbf{K}_{2354} \mathrm{DELR}, \mathbf{G}_{2488} \mathrm{NPSG}$, $\mathbf{Y}_{2528} \mathrm{GDD}$ and $\mathbf{F}_{2577} \mathrm{LKR}$ ) in 3D [34] are also present in the isolate from this study.

Comparing the $\mathrm{P} 1^{\mathrm{cap}} / 2 \mathrm{C}^{\mathrm{hel}} / 3 \mathrm{C}^{\mathrm{pro}} / 3 \mathrm{D}^{\mathrm{pol}}$ protein products of waxbill/DB01/HUN/2014 to the closest relative, passerivirus A1 strain thrush/Hong Kong/00356/2007 (GU182406) and the corresponding proteins of representative picornaviruses (Supplementary Table 1), these proteins showed $38.9 \%, 60.9 \%$ and $69.3 \%$ aa sequence identity, respectively. Phylogenetic analysis of the predicted protein products these coding regions showed that the strain from this study clustered together with passeriviruses of the family Picornaviridae (Fig. 3A). 

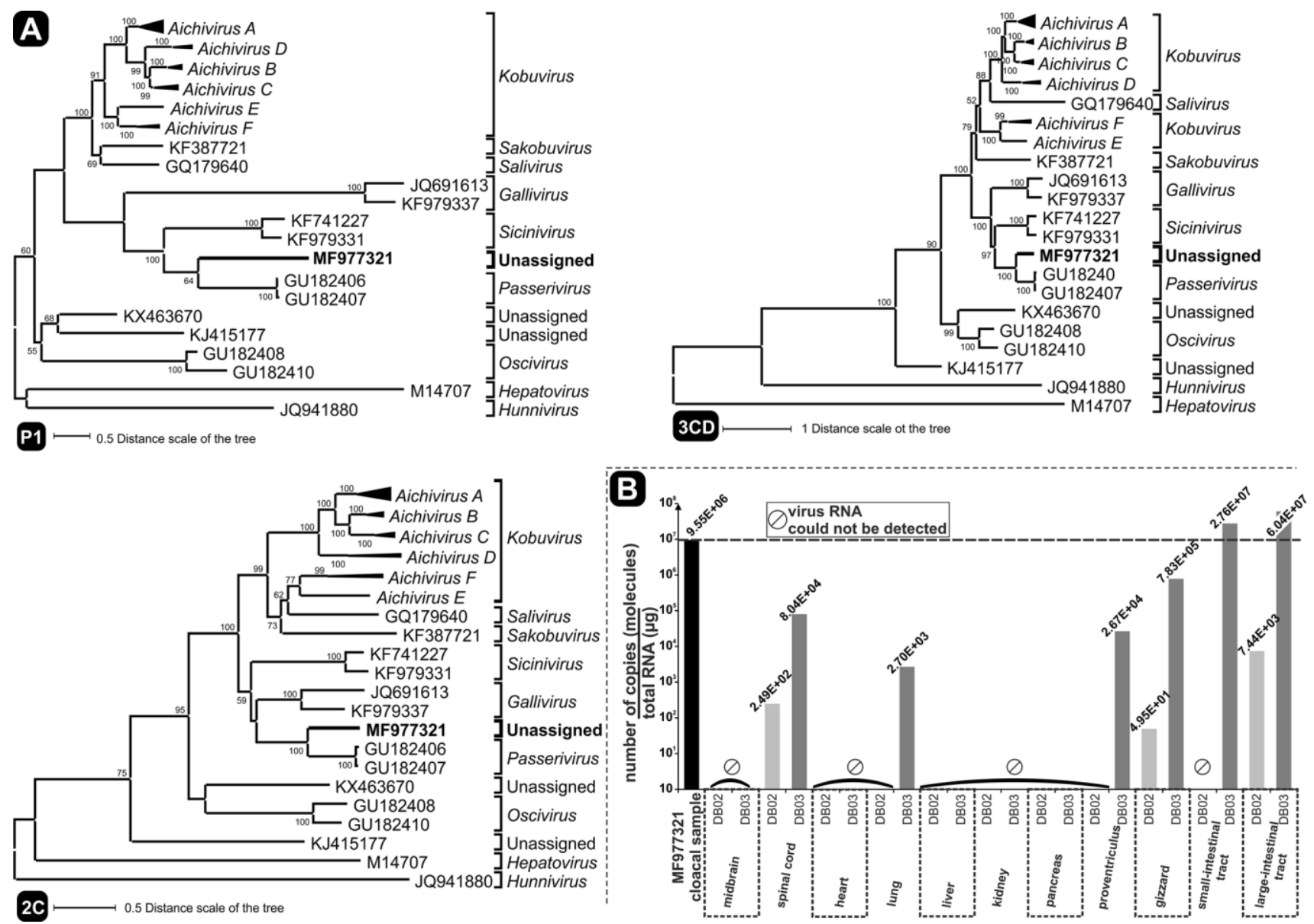

Fig. 3 A) Phylogenetic analysis of finch picornavirus strain waxbill/ DB01/HUN/2014 (MF977321 in bold) and representative picorna- viruses, based on the complete $\mathrm{P} 1$ cap, $2 \mathrm{C}^{\text {hel }}$ and $3 \mathrm{C}^{\mathrm{pro}} / 3 \mathrm{D}^{\mathrm{pol}}$ nucleotide sequences. Two strains, BHUV1/2008/HUN (JQ941880, hunnivirus A1, genus Hunnivirus) and HM-175 (M14707, hepatitis A virus, genus Hepatovirus) were used as outgroups in each phylogenetic tree. Evolutionary analysis was conducted in MEGA6 [25], and evolutionary history was inferred using the ML method based on the GTR model with discrete gamma distribution $(+\mathrm{G})$, allowing evolutionarily invariable sites $(+\mathrm{I})$, and bootstrap values were determined for 1000 replicates. The tree is drawn to scale, with branch lengths measured in the number of substitutions per site. Species within the genus Kobuvirus were grouped, and representatives of the type species were used in each phylogenetic tree (Aichivirus A, KF831027, KJ958930, KM091960, JN387133, JF755427, JQ898342, AB040749, and KJ934637; Aichivirus B, GU245693, KF006985, and AB084788; Aichivirus C, KF793927, EU787450, and JX177612; Aichivirus D, LC055960 and LC055961; Aichivirus E, KT325852; Aichivirus F, KJ641686 and KJ641691; FFUP1/Portugal/2012, KF387721; hu/NG-J1/Nigeria/2007, GQ179640; turkey/ HUN/M176/2011, JQ691613; ch/518C/Hong Kong/2010, KF979337; newt/II-5-Pilis/2014/HUN, KX463670; tortoise/UF4/USA/2009， KJ415177; robin/Hong Kong/10717/2006， GU182408; thrush/Hong Kong/10878/2006, GU182410; thrush/Hong Kong/00356/2007, GU182406; thrush/Hong Kong/00805/2007, GU182407; ch/ UCC001/Eire, KF741227; ch/55C/Hong Kong/2008, KF979331. B) Quantitative analysis of novel finch picornavirus RNA in a violet- eared waxbill DB01 cloacal sample and DB02, DB03 organs and intestines by real-time RT-PCR using SYBR Green I chemistry. The $y$-axis represents the number of genome copies per total RNA $(\mu \mathrm{g})$. 
of $6.58 \times 10^{10}$ genomic copies per $\mathrm{ml}$ of faeces $\left(\mathrm{SD}: \pm 3.37 \times 10^{9}\right)$ in the cloacal sample. The organs of the other two dead violet-eared waxbills - DB02 and DB03 - were also tested by RT-PCR using the screening primer pair S13-Passeri- 3D-R/F. Nine out of 24 tissue samples were RT-PCR positive (Fig. 3B), and all were confirmed by direct nucleotide sequencing to contain passerivirus sequences. The nucleotide sequence of the viral RNA from organs of DB02 was identical to that of waxbill/DB01/HUN/2014, but a sequence with four nucleotide differences with $98 \%$ nt identity was detected in tissue samples of DB3. These mutations resulted in one amino acid change, isoleucine to threonine at aa position 2587 in the $3 \mathrm{D}^{\mathrm{pol}}$ region. Passerivirus RNA was also detected by qPCR in spinal cord (DB02 and DB03), lung (DB03), gizzard (DB02 and DB03) and proventriculus (DB03), small intestine (DB03) and large intestine (DB02 and DB03) specimens. The viral copy number relative to the amount of total RNA ( $\mu \mathrm{g})$ was the highest in the large intestine of DB03 (higher than in the cloacal sample of DB01), but a high viral load was also detected in other parts of the enteric tract, lung and spinal cord (Fig. 3B).

The Aves class is considered to be the largest class of vertebrates, with over 10,000 currently surviving species. For that very reason, live wild birds could be the key factors for transmission of agents of infectious diseases and could carry and spread potentially unrecognized pathogens to become an emerging risk (http://www.onehealthinitiative.com/). On the other hand, our knowledge of viral bird diseases is still fragmentary. The first comprehensive screening of viral agents in birds was published by Woo et al. in 2010 [34]. In that study, 201 different wild bird species of 50 avian families were analysed to investigate the presence of viral agents. The prototype passeriviruses (formerly turdivirus 1) were identified in dead robins and thrushes (Cosychus saularis and Turdus sp. in avian family Turdidae), but among the tested respiratory and alimentary specimens collected from 515 different dead estrildid finches (family Estrildidae), passeriviruses were not found using RT-PCR [34]. In the present study, we report the detection and complete genome characterization of a novel passerivirus from an enteric outbreak with high mortality in an estrildid finch population.

To date, strains thrush/Hong Kong/00356/2007 (GU182406; NC_014411) and thrush/Hong Kong/00805/2007 (GU182407) have been the only known members of the genus Passerivirus, family Picornaviridae [1,8]. However, the 5'end of both viral genomes could be incomplete based on our analysis. The finch picornavirus strain waxbill/DB01/HUN/2014 showed a passerivirus-like genome organization with high amino acid sequence identity $38.9 \%, 61.6 \%, 69.6 \%$ in $\mathrm{P} 1$ cap, $2 \mathrm{C}^{\text {hel }}$ and $3 \mathrm{C}^{\mathrm{pro}} \mathrm{D}^{\mathrm{pol}}$, respectively, to passerivirus $\mathrm{A} 1$ (GU182406). According to the taxonomic genus demarcation criteria of the International Committee on Taxonomy of Viruses (ICTV) (http://www. picornastudygroup.com/definitions/genus_definition.htm), novel picornavirus genera are 
defined if internal ribosomal entry site (IRES) structures are not homologues and if the amino acid (aa) sequence identity of the orthologous proteins $\mathrm{P} 1^{\text {cap }}, 2 \mathrm{C}^{\text {hel }}, 3 \mathrm{C}$ pro and $3 \mathrm{D}^{\text {pol }}$ is less than $34 \%, 36 \%$, $36 \%$ and $36 \%$, respectively. The novel finch picornavirus strain waxbill/DB01/HUN/2014 can therefore be considered a member of the genus Passerivirus, and it appears to be the first member of this genus for which a complete genome sequence has been obtained, including the type-V IRES in the 5'UTR and the complete leader (L) sequence between the 5'UTR and the P1 regions.

An origin of replication (ORI) structure with a pseudoknot is common in picornaviruses with typeV IRES elements [4], but we were not able to identify such a structure in the isolate described here. It instead contains three hairpin structures at the beginning of the 5'UTR region, as has been found in murine kobuvirus 1 strain M-5/USA/2010 (JF755427) and rabbit kobuvirus 1 strain rabbit01/2013/HUN (KT325852) [35, 36]. A converse example is the porcine kobuvirus 1 strain sw/S-1-HUN/2007 (EU787450), in which the ORI secondary structure with the pseudoknot is followed by type-IV IRES structures [37]. This observation strengthens the hypothesis that structural elements/modules can be transferred or exchanged between (picorna)virus genomes by recombination, maintaining genetic diversity and virus viability in a new host species [4, 38-40]. The domains I, J, K and the $\mathrm{Y}_{\mathrm{n}}-\mathrm{X}_{\mathrm{m}}$-tract between domain $\mathrm{K}$ and the initiation AUG motif are believed to be indispensable elements of type-V IRES elements [4, 31, 32]. Focusing on the $\mathrm{Y}_{\mathrm{n}}-\mathrm{X}_{\mathrm{m}}$-tract, the pyrimidine-rich region $\left(\mathrm{Y}_{\mathrm{n}}\right)$ in the finch picornavirus is exceptionally long and is followed by a long spacer $\left(X_{m}\right)$ similar to that in the oscivirus A2 strain thrush/ Hong Kong/10878/2006 (GU182410) (data not shown).

Among picornavirus proteins, the leader (L) protein shows the greatest diversity, both in function and in size $[11,12]$. More than half of the known members of picornavirus genera encode a leader (L) protein at the 5'end of the ORF (http://www.picornaviridae.com), but only a few of them have a known function [41-45]. The PPSLP (PxLPxNxxxxxxDD) aa motif in the L protein of waxbill/ DB01/HUN/2014 is present in other picornaviruses of different genera, suggesting a common origin and analogous function of this gene [33]. Despite the amino acid sequence similarity between the leader proteins of the waxbill strain and two other bird-origin picornaviruses, passerivirus A1 strain thrush/Hong Kong/00356/2007 (GU182406) and sicinivirus A1 strain ch/UCC001/Eire (KF741227), the function or the biological activity of this L protein is still unknown.

The order Passeriformes is the largest of all orders in the Aves class, including more than 50\% of all bird species. The family Estrildidae includes many finch species. These small birds are natively found throughout the old world tropics and Australasia [18]. Estrildid finches are popular as exotic pets, for home-rearing, and for exhibition in Hungary and throughout Europe. Stock farmers in Belgium, the 
Nether- lands, and Germany successfully breed estrildids, often with no documented information about the origin of the first few generations. Ideally, incoming birds should be isolated in a separate cage/building for 30-days or longer. With this quarantine procedure, many unexpected contagion sources can be excluded. In this case, the incubation period appeared to be no more than 7-10 days [46] between suspected exposure to the virus and onset of clinical signs.

Although there is some evidence that the picornavirus was related to the disease, i) passerivirus sequence reads from the cloacal specimen represents up to the $90 \%$ of the total viral metagenomic sequence reads, suggesting an enterically transmitted agent, ii) samples from more than one affected bird (three of the three tested dead estrildid finches) with similar symptoms from the same outbreak were positive for this novel passerivirus, iii) the passerivirus genome sequence is present in different organs, indicating an exta-intestinal and generalized infection, and iv) a high passerivirus viral load was measured in a cloacal specimen, a direct etiological connection and confirmation is lacking in this retrospective study. FFPE specimens were not available for in situ hybridization, and there was no inoculation study of naïve animals or additional testing of healthy and sick populations, which could confirm that the virus might be correlated with disease. Passeriviruses in the family Picornaviridae might be responsible for sporadic disease in wild birds and outbreaks in home-kept birds with fatal outcome. Further molecular epidemiological studies are needed to explore the diversity, biology, and detailed pathogenesis of passerivirus in domestic and wild bird species.

Acknowledgements The authors especially thank Tibor Jantyik for providing the dead estrildid finches and for his helpful comments. Thanks to Béla Markos (Animal Health Veterinary Laboratory LTD.) for giving laboratory information about the birds that were examined. This work was supported by grants from the Hungarian Scientific Research Fund (OTKA/NKFIH K111615). P.P and B.Á. were sup- ported by the János Bolyai Research Scholarship of the Hungarian Academy of Sciences.

\section{Compliance with ethical standards}

Funding This study funded by Hungarian Scientific Research Fund (OTKA/NKFIH K111615) by the Hungarian Nature Research Society.

Conflict of interest The authors declare that they have no conflict of interest.

Ethical approval All applicable international, national, and/or institutional guidelines for the care and use of animals were followed. 
Supplementary Table 1. The amino acid (aa) identity of a finch picornavirus strain waxbill/DB01/HUN/2014 (MF977321) to the corresponding regions of representative picornaviruses. The highest aa values are bolded. The identity calculation was carried out using BioEdit

[26], based on the codon-based aligned nucleotide sequences by MEGA6 [25].

\begin{tabular}{|c|c|c|c|c|c|c|}
\hline \multirow[t]{2}{*}{ Genus } & \multirow[t]{2}{*}{ Type } & \multirow[t]{2}{*}{ Strain } & \multirow[t]{2}{*}{ Acc. num. } & \multicolumn{3}{|c|}{$\begin{array}{c}\text { waxbill/DB01/HUN/2014 } \\
\text { (MF977321) }\end{array}$} \\
\hline & & & & P1 ${ }^{\text {cap }}$ & $2 C^{\text {hel }}$ & 3C ${ }^{\text {pro }} \mathbf{D}^{\text {pol }}$ \\
\hline \multirow{19}{*}{ Kobuvirus } & \multirow{3}{*}{ Feline kobuvirus 1 (FeKV-1) } & FK-13/South Korea/2011 & KF831027 & 31.9 & 45.7 & 51.7 \\
\hline & & 12D240/South Korea/2012 & KJ958930 & 33 & 46.3 & 51.1 \\
\hline & & $\mathrm{TE} / 52 / \mathrm{IT} / 13$ & KM091960 & 32.9 & 46.1 & 51.6 \\
\hline & \multirow[t]{2}{*}{ Murine kobuvirus 1 (MuKV-1) } & M-5/USA/2010 & JF755427 & 32.8 & 46.8 & 50.6 \\
\hline & & KoV-SewKTM (Nepal/2009) & JQ898342 & 30.1 & 46.1 & 49.9 \\
\hline & Canine kobuvirus $1(\mathrm{CaKV}-1)$ & $\operatorname{dog} / \mathrm{AN} 211 \mathrm{D} / \mathrm{USA} / 2009$ & JN387133 & 31.2 & 45.4 & 50 \\
\hline & Aichi virus 1 (AiV-1) & A846/88 & AB040749 & 32.2 & 45.9 & 51.5 \\
\hline & European roller kobuvirus 1 (ERKV-1) & SZAL6-KoV/2011/HUN & KJ934637 & 32.9 & 45.2 & 49.2 \\
\hline & Bovine kobuvirus 1 (BKV-1) & bov/U-1/Japan & AB084788 & 33 & 46 & 50.1 \\
\hline & Ferret kobuvirus (FKV) & ferret/MpKoV38/NL/2010 & KF006985 & 32.4 & 45.9 & 51.5 \\
\hline & Ovine kobuvirus 1 (OKV-1) & sheep/TB3/HUN/2009 & GU245693 & 32.8 & 46.9 & 50.8 \\
\hline & \multirow[t]{2}{*}{ Porcine kobuvirus 1 (PKV-1) } & sw/S-1-HUN/2007 & EU787450 & 32.4 & 44.9 & 49.8 \\
\hline & & wb/WB-1-HUN/2011 & JX177612 & 32.7 & 45 & 48.7 \\
\hline & Caprine kobuvirus (CapKV) & black goat/12Q108/KOR/2012 & KF793927 & 32 & 45.5 & 49.7 \\
\hline & Kagovirus $1(\mathrm{KV}-1)$ & cattle/Kagoshima-1-22-KoV/2014/JPN & LC055961 & 32 & 44.2 & 49.6 \\
\hline & Kagovirus $2(\mathrm{KV}-2)$ & cattle/Kagoshima-2-24-KoV/2015/JPN & LC055960 & 30.8 & 43.9 & 49.2 \\
\hline & Rabbit kobuvirus 1 (RKV-1) & Rabbit01/2013/HUN & KT325852 & 31.8 & 42.7 & 49.8 \\
\hline & Aichivirus F1 (AiV-F1) & BtMr-PicoV/JX2010 & KJ641686 & 32.6 & 46.1 & 48.8 \\
\hline & Aichivirus F2 (AiV-F2) & BtMf-PicoV-2/GD2012 & KJ641691 & 32.5 & 44 & 51.2 \\
\hline Salivirus & Salivirus A1 (SaV-A1) & hu/NG-J1/Nigeria/2007 & GQ179640 & 31.9 & 46 & 46 \\
\hline Sakobuvirus & Sakobuvirus A1 (SakV-A1) & FFUP1/Portugal/2012 & KF387721 & 30.7 & 44.6 & 49.9 \\
\hline \multirow[t]{2}{*}{ Gallivirus } & Chicken gallivirus $1(\mathrm{ChGV}-1)$ & chicken/518C/Hong Kong/2010 & KF979337 & 29.4 & 46.5 & 54.3 \\
\hline & Gallivirus A1 (GV-A1) & turkey/M176/2011/HUN & JQ691613 & 29 & 43.9 & 55 \\
\hline \multirow[t]{2}{*}{ Sicinivirus } & Sicinivirus A1 (SiV-1) & chicken/UCC001/Eire & KF741227 & 34.7 & 50.3 & 57.6 \\
\hline & unassigned siciniviruses & chicken/55C/Hong Kong/2008 & KF979331 & 34 & 49.3 & 58.1 \\
\hline
\end{tabular}




\begin{tabular}{|c|c|c|c|c|c|c|}
\hline \multirow[t]{2}{*}{ Passerivirus } & \multirow[t]{2}{*}{ Passerivirus A1 (PasV-A1) } & thrush/Hong Kong/00356/2007 & GU182406 & 38.9 & 60.9 & 69.3 \\
\hline & & thrush/Hong Kong/00805/2007 & GU182407 & 38.9 & 61.6 & 69.6 \\
\hline Unassigned & Tortoise rafivirus A1 & tortoise/UF4/USA/2009 & KJ415177 & 31 & 38.7 & 43.9 \\
\hline Oscivirus & Oscivirus A1 & robin/Hong Kong/10717/2006 & GU182408 & 30.9 & 41.3 & 48.8 \\
\hline Hepatovirus & Human hepatitis A virus (HHAV) & HM-175 & M14707 & 24.6 & 33.9 & 34.5 \\
\hline Hunnivirus & Hunnivirus A1 (HuV-A1) & BHUV1/2008/HUN & JQ941880 & 29.1 & 35.5 & 34.7 \\
\hline
\end{tabular}




\section{References}

1. Knowles NJ, Hovi T, Hyypiä T et al (2012) Picornaviridae. In: King AMQ, Adams MJ, Carstens EB, Lefkowitz EJ (eds) Virus taxonomy: classification and nomenclature of viruses: ninth report of the International Committee on Taxonomy of Viruses. Elsevier, San Diego, pp 855-880

2. Sasaki J, Nagashima S, Taniguchi K (2003) Aichi virus leader protein is involved in viral RNA replication and encapsidation. J Virol 77:10799-10807

3. Hellen CU, de Breyne S (2007) A distinct group of hepacivirus/pestivirus-like internal ribosomal entry sites in members of diverse picornavirus genera: evidence for modular exchange of functional noncoding RNA elements by recombination. J Virol 81:5850-5863

4. Sweeney TR, Dhote V, Yu Y, Hellen CU (2012) A distinct class of internal ribosomal entry site in members of the Kobuvirus and proposed Salivirus and Paraturdivirus genera of the Picornaviridae. J Virol 86:1468-1486

5. Asnani M, Kumar P, Hellen CUT (2015) Widespread distribution and structural diversity of type IV IRESs in members of Picornaviridae. Virology 478:61-74

6. Pankovics P, Boros Á, Kiss T et al (2015) Identification and complete genome analysis of kobuvirus in faecal samples of European roller (Coracias garrulus): for the first time in a bird. Arch Virol 160:345-351

7. Paul A, Wimmer E (2015) Initiation of protein-primed picornavirus RNA synthesis. Virus Res 206:12-16

8. Woo PC, Lau SK, Choi GK et al (2012) Natural occurrence and characterization of two internal ribosomal entry site elements in a novel virus, canine picodicistrovirus, in the picornavirus-like superfamily. J Virol 86:2797-2808

9. Reuter G, Boros Á, Földvári G et al (2017) Dicipivirus (family Picornaviridae) in wild Northern white-breasted hedgehog (Erinaceus roumanicus). Arch Virol (article in press)

10. Palmenberg A, Neubauer D, Skern T (2010) Genome organiza- tion and encoded proteins. In: Ehrenfeld E, Domingo E, Roos RP (eds) The Picornaviruses. ASM Press, Washington, DC

11. Flather D, Semler BL (2015) Picornaviruses and nuclear functions: targeting a cellular compartment distinct from the replication site of a positive-strand RNA virus. Front Microbiol $6: 594-621$

12. Pankovics P, Boros Á, Tóth Z et al (2017) Genetic characterization of a second novel picornavirus from and amphibian host, smooth newt (Lissotriton vulgaris). Arch Virol 162:1043-1050

13. McKnight KL, Lemon SM (1998) The rhinovirus type 14 genome contains an internally located RNA structure that is required for viral replication. RNA 4:1569-1584 
14. Yang Y, Yi M, Evans DJ et al (2008) Identification of a con- served RNA replication element (cre) within the 3Dpol-coding sequence of hepatoviruses. J Virol 82:10118-10128

15. Steil BP, Barton DJ (2009) Cis-active RNA elements (CREs) and picornavirus RNA replication. Virus Res 139:240-252

16. Boros Á, Pankovics P, Reuter G (2014) Avian picornaviruses: Molecular evolution, genome diversity and unusual genome features of a rapidly expanding group of viruses in birds. Infect Genet Evol 28:151-166

17. Ericson PGP, Johansson US (2003) Phylogeny of Passerida (Aves: Passeriformes) based on nuclear and mitochondrial sequence data. Mol Phylogenet Evol 29:126-138

18. Arnaiz-Villena A, Ruiz-del-Valle V, Gomez-Prieto P et al (2009) Estrildinae finches (Aves, Passeriformes) from Africa, South Asia and Australia: a molecular phylogeographic study. Open Ornithol J 2:29-36

19. Clement P, Harris P, Davies J (1993) Finches and sparrows. An Identification guide. Christopher Helm, London

20. Phan TG, Vo NP, Boros Á et al (2013) The viruses of wild pigeon droppings. PLoS One $8: \mathrm{e} 72787$

21. Victoria JG, Kapoor A, Li L et al (2009) Metagenomic analyses of viruses in stool samples from children with acute flaccid paralysis. J Virol 83:4642-4651

22. Chomczynski P (1993) A reagent for the single-step simultaneous isolation of RNA, DNA and proteins from cell and tissue samples. Biotechniques 15:532-535

23. Liu YG, Chen Y (2007) High-efficiency thermal asymmetric interlaced PCR for amplification of unknown flanking sequences. Biotechniques 43:649-650

24. Boros Á, Cs Nemes, Pankovics P et al (2012) Identification and complete genome characterization of a novel picornavirus in turkey (Meleagris gallopavo). J Gen Virol 93:2171-2182

25. Tamura K, Stecher G, Peterson D et al (2013) MEGA6: molecular evolutionary genetics analysis version 6.0. Mol Biol Evol 30:2725-2729

26. Hall TA (1999) BioEdit: a user-friendly biological sequence alignment editor and analysis program for Windows 95/98/NT. Nucl Acids Symp Ser 41:95-98

27. Reuter JS, Mathews DH (2010) RNAstructure: software for RNA secondary structure prediction and analysis. BMC Bioinform 11:129

28. Lorenz R, Bernhart SH, Höner zu Siederdissen C et al (2011) ViennaRNA Package 2.0. Algorithms Mol Biol 6:26

29. Bullman S, Kearney K, O’Mahony M et al (2014) Identification and genetic characterization of 
novel picornavirus from chickens. J Gen Virol 95:1094-1103

30. Kozak M (1987) An analysis of 5'-noncoding sequences from 699 vertebrate messenger RNAs. Nucleic Acids Res 15:8125-8148

31. Jang SK, Pestova TV, Hellen CU et al (1990) Cap-independent translation of picornavirus RNAs: structure and function of the internal ribosomal entry site. Enzyme 44:292-309

32. Pilipenko EV, Gmyl AP, Maslova SV et al (1992) Prokaryotic-like cis elements in the capindependent internal initiation of transla- tion on picornavirus RNA. Cell 68:119-131

33. Reuter G, Pankovics P, Boros Á (2017) Saliviruses - the first knowledge about a newly discovered human picornavirus. Rev Med Virol 27:1-10

34. Woo PC, Lau SK, Huang Y et al (2010) Comparative analysis of six genome sequences of three novel picornaviruses, turdiviruses 1,2 and 3, in dead wild birds, and proposal of two novel genera, Orthoturdivirus and Paraturdivirus, in the family Picornaviridae. J Gen Virol 91:2433-2448

35. Phan TG, Kapusinszky B, Wang C et al (2011) The fecal viral flora of wild rodents. PLoS Pathog 7:e1002218

36. Pankovics P, Boros Á, Bíró H et al (2015) Novel picornavirus in domestic rabbits (Oryctolagus cuniculus var. domestica). Infect Genet Evol 37:117-122

37. Reuter G, Boldizsár Á, Pankovics P (2009) Complete nucleotide and amino acid sequences and genetic organization of porcine kobuvirus, a member of a new species in the genus Kobuvirus, family Picornaviridae. Arch Virol 154:101-108

38. Botstein D (1980) A theory of modular evolution for bacterio- phages. Ann N Y Acad Sci 354:484-490

39. Belsham GJ, Sonenberg N (2000) Picornavirus RNA translation: roles for cellular proteins. Trends Microbiol 8:330-335

40. Reuter G, Boros A, Pankovics P et al (2010) Kobuvirus in domes- tic sheep, Hungary. Emerg Infect Dis 16:869-870

41. Chen HH, Kong WP, Roos RP (1995) The leader peptide of Theiler's murine encephalomyelitis virus is a zinc-binding protein. J Virol 69:8076-8078

42. Sasaki J, Nagashima S, Taniguchi K (2003) Aichi virus leader protein is involved in viral RNA replication and encapsidation. J Virol 77:10799-10807

43. Tseng CH, Tsai HJ (2007) Sequence analysis of a duck picornavirus isolate indicates that it together with porcine enterovirus type 8 and simian picornavirus type 2 should be assigned to a new picornavirus genus. Virus Res 129:104-114

44. Lau SKP, Woo PCY, Lai KKY et al (2011) Complete genome analysis of three novel 
picornaviruses from diverse bat species. J Virol 85:8819-8828

45. Wang C, Vernon R, Lange $\mathrm{O}$ et al (2010) Prediction of structures of zinc-binding proteins through explicit modelling of metal coordination geometry. Protein Sci 19:494-506

46. Prattis SM, Cioffee CJ, Reinhard G et al (1990) A retrospective study of disease and mortality in zebra finches. Lab Anim Sci. 40:402-405

\section{Web references}

47. Knowles NJ (2017) The picornavirus pages. http://www.picornav iridae.com. Accessed 21 Aug 2017

48. Handbook of the Birds of the World Alive (HBV). http://www. hbw.com/order/passeriformes. Accessed 21 Aug 2017

49. Integrated Taxonomic Information System (ITIS). https://www. itis.gov/. Accessed: 21 Aug 2017

50. The Internet IBC Bird Collection. http://www.hbw.com/ibc/fami ly/waxbills-estrildidae. Accessed 21 Aug 2017

51. International Committee on Taxonomy of Viruses (ICTV), Picornaviridae Study Group. http://www.picornastudygroup.com/definitions/genus_definition.htm. Accessed 21 Aug 2017 